\title{
Cu-Catalyzed Selective Mono- $N$-pyridylation: Direct Access to 2-AminoDMAP/Sulfonamides as Bifunctional Organocatalysts
}

\author{
Murat Isik ${ }^{\dagger}$ and Cihangir Tanyeli* \\ Department of Chemistry, Middle East Technical University, 06800 Ankara, Turkey \\ Supporting Information
}

ABSTRACT: Direct and selective mono- $N$-pyridylation of trans- $(R, R)$-cyclohexane-1,2-diamine is described here. Facile preparation of a novel chiral 2-aminoDMAP core catalaphore via $\mathrm{Cu}$ catalysis has led to the development of various sulfonamide/2-aminoDMAPs as bifunctional acid/base organocatalysts (most in two steps overall), which have been shown to very effectively promote asymmetric conjugate addition of acetylacetone to trans- $\beta$-nitroolefins with good to excellent yields (87-93\%) and enantioselectivites (up to $99 \%)$.

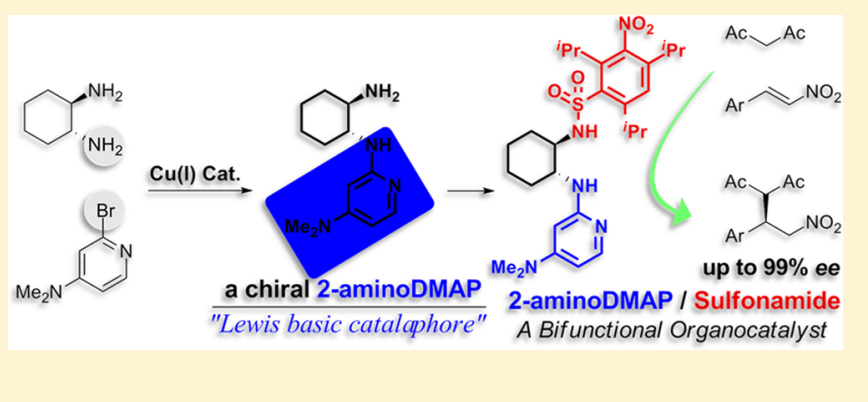

\section{INTRODUCTION}

Chiral 4-(N,N-dimethylamino)pyridine (DMAP) analogues offer unique reactivity and versatility as Lewis base catalysts in a wide array of reactions where some prominent examples include kinetic resolution (KR) of sec-alcohols and sec-amines and Steglich rearrangement. ${ }^{1}$ Although numerous chiral variants have been reported to date, due to challenges for effective chirality introduction to the DMAP unit (on account of its highly symmetrical nature), synthetic protocols often require multiple steps, and more practical and rational designs still remain elusive. ${ }^{2}$ The catalytic role of chiral DMAPs resides mainly in their nucleophilic character particularly for KR of secalcohols. ${ }^{1}$ However, a planar chiral 4-dialkylaminopyridine developed by Fu is shown to effectively catalyze the addition of nitrogen nucleophiles to prochiral ketenes, wherein the DMAP unit acts as a Brønsted base. ${ }^{3}$ Following their ground-breaking work, DMAP-pyrrolidine hybrids are reported to be very effective chiral catalysts in Michael reaction in a work by Kotsuki, ${ }^{4}$ and this unequivocally reveals the Brønsted basic nature of DMAP as well. More interestingly, a recent report by Wulff $^{5}$ clearly demonstrates the dramatic impact of superior base (DMAP over triaklylamines ${ }^{6}$ ) in bifunctional organocatalyst design. ${ }^{7}$ Remarkably important is Johnston's both $C_{1}$ and $C_{2}$-symmetric bisamidine (BAM) type catalysts, ${ }^{8}$ which highlight fruitful emergence of relatively unexplored 2-aminopyridine chemistry in asymmetric organocatalysis. ${ }^{8,9}$ transCyclohexane-1,2-diamine, arguably the most frequently addressed vicinal chiral diamine, has proven its broad utility in a diverse array of catalyst systems (from salen type transition metal complexes ${ }^{10}$ to bifunctional acid/base organocatalysts ${ }^{11}$ ) as a "privileged"12 chiral catalyst backbone. Consequently, there is a significant demand to evolve novel practical methodologies targeting direct mono- $N$-functionalization of such $C_{2}$-symmetrical diamines. ${ }^{13}$
Herein, we have anticipated that the chiral 2-aminoDMAP ${ }^{14}$ 1 derived from trans-cyclohexane-1,2-diamine could serve as a versatile Lewis basic catalaphore, and introduction of various $\mathrm{H}$ bond donor entities via modification of the remaining primary amine might lead to discovery of novel reactivities in the context of bifunctional acid/base catalyst development (Figure $1)$.

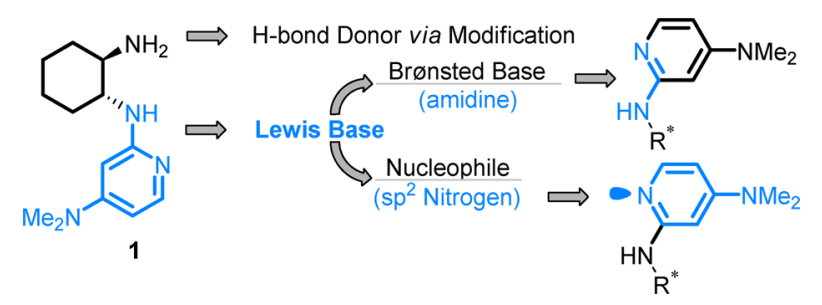

Figure 1. Catalyst design rationale.

In principle, it was thought that $2-\mathrm{N}$-alkylamino and 4dimethylamino disubstituted chiral pyridine 1 might act as both Brønsted base and nucleophile, due to two electron-donor nitrogens on the pyridine ring rendering it highly electron-rich, which may amplify the scope of the reactions to be catalyzed.

\section{RESULTS AND DISCUSSION}

To afford compound 1, we initially explored the possibility of Pd-catalyzed Buchwald-Hartwig N-arylation ${ }^{15}$ of the $(1 R, 2 R)$ cyclohexane-1,2-diamine with 2-haloDMAPs $2 \mathbf{a}, \mathbf{b} .{ }^{16}$ Of the various conditions investigated, Wulff's coupling protocol was adapted first; however, no trace of target compound 1 was observed. $^{5,17}$ In all of our efforts, direct mono- $N$-pyridylation attempts by Pd-catalysis failed. ${ }^{18}$

Received: December 13, 2012

Published: January 18, 2013 
Realizing unsatisfactory results with palladium chemistry, we turned our attention to a copper-catalyzed modified Ullmann coupling reaction that is generally complementary to the former comprising air-sensitive and high-priced bis-phosphine ligands. In a miscellaneous screening of varied nucleophiles for $\mathrm{Cu}$ catalyzed $\mathrm{C}-\mathrm{N}$ bond-forming reactions, Buchwald observed a selective mono- $N$-arylated product in moderate yield while using trans-cyclohexane-1,2-diamine ligand as the nucleophile and $p$-bromotoluene as the electrophile. ${ }^{19}$ Inspired by their work, we initiated our copper catalysis studies (Table 1).

Table 1. Optimization Studies for Cu-Catalyzed Selective Mono- $N$-pyridylation ${ }^{a}$

$1,4-\mathrm{Dioxane}$
$110^{\circ} \mathrm{C}, 24 \mathrm{~h}, \mathrm{Ar}$

${ }^{a}$ Reaction conditions: trans-cyclohexane-1,2-diamine (1.2 mmol), 2ac $(1.0 \mathrm{mmol})$, base $(2.0 \mathrm{mmol}), 20 \mathrm{~mol} \% \mathrm{CuX}$, and $1 \mathrm{~mL}$ of $1,4-$ dioxane were stirred at $110^{\circ} \mathrm{C}$ for $24 \mathrm{~h}$ under $\mathrm{Ar}$ atm. ${ }^{b}$ Isolated yields. ${ }^{c}$ Reaction was carried out in the absence of copper source with 2haloDMAPs (2a, $\mathbf{2 b}$, and $\mathbf{2 c}$ ); however no mono- or disubstituted coupling products were observed.

Investigation of copper-free $S_{N} A r$ type reactions showed no trace of coupling products 1 and 3 (entry 1, Table 1). To our delight, we could isolate the target compound $\mathbf{1}$ in appreciable yields using $\mathrm{K}_{3} \mathrm{PO}_{4}$ and $\mathrm{Cs}_{2} \mathrm{CO}_{3}$, through base screening $\left(\mathrm{K}_{3} \mathrm{PO}_{4}, \mathrm{~K}_{2} \mathrm{CO}_{3}, \mathrm{Cs}_{2} \mathrm{CO}_{3}, \mathrm{NaO}{ }^{t} \mathrm{Bu}\right.$, and $\left.\mathrm{KO}^{t} \mathrm{Bu}\right)$ experiments (entries 2-6). Because of its much lower price and relatively higher reactivity, tribasic potassium phosphate was chosen as the base for further optimization studies. The effect of the nature of the electrophile (2-haloDMAP $2 a$ and $2 c$ ) was investigated next (entries 7 and 8). $2 a$ and $2 c$ resulted in poorer conversions, where the latter produced compound $3^{20}$ as the major product. Selectivity was considerably reduced ( $26 \%$ vs $32 \%$ ) in the case of $2 \mathrm{c}$, which proved to be a highly reactive substrate for this transformation (entry 8). ${ }^{21}$ The effect of copper source was also investigated as the final work to optimize the yield of 1 (entries 9 and 10). Among the copper(I) species $(\mathrm{Cl}, \mathrm{Br}$, and $\mathrm{I}), \mathrm{CuBr}$ gave the best result (entry 9). To the best of our knowledge, this is the first successful example of direct and selective mono- $N$-heteroarylation of a vicinal diamine. ${ }^{18}$ Scheme 1 presents the speculative mechanism for the formation of products 1 and 3 in parallel with the previously published similar work in the literature. $^{22}$

\section{Scheme 1. Putative Operating Catalytic Cycle}
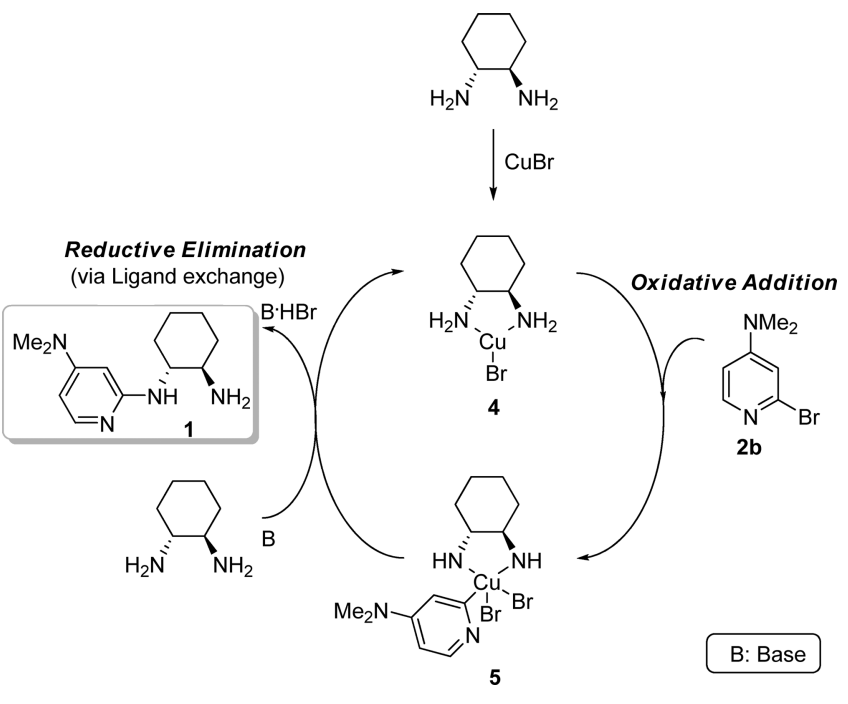

The scenario is presumed to start with the chelation of the $(1 R, 2 R)$-cyclohexane-1,2-diamine with the $\mathrm{CuBr}$ to form activated copper complex 4 , and subsequent oxidative addition of 2-bromoDMAP $\mathbf{2 b}$ is thought to generate unstable pentacoordinate reactive intermediate 5 . In the presence of a base, intermediate $\mathbf{5}$ is speculated to undergo reductive elimination to afford $\mathbf{1}$, which is exchanged with the sterically less demanding diamine ligand. Then the catalytically active copper species 4 would be ready to operate in the forthcoming cycle. Furthermore, a possible speculation for the generally observed selectivity of $\mathbf{1}$ over $\mathbf{3}$ would be as follows: Competitive ligation of the product $\mathbf{1}$ and diamine substrate to the copper is supposed to result in favor of the sterically less demanding diamine, since the DMAP unit of 1 , upon coordination to the copper metal, might eradicate the nucleophilicity of the remaining primary amine. As a result, further arylation of $\mathbf{1}$ is speculated to proceed more slowly than the competing free ligand.

In his recent reports, Johnston observed consistently higher stereodifferentiation by the $C_{1}$-symmetric BAM catalysts over the $C_{2}$-symmetric ones. Indeed, synthesis of the former calls for the selective mono- $N$-heteroarylation of trans-cyclohexane-1,2diamine for practical reasons. ${ }^{8}$ For this purpose, the value of the mono- $N$-heteroarylative process that we developed herein was clearly shown to be a high-yielding shortcut method for the formal synthesis of Johnston's $C_{1}$-symmetric BAM catalysts (Scheme 2).

Successful synthesis of 2 -aminoDMAP 1 readily in only one step encouraged us to investigate the catalytic potential of this basic catalaphore unit in pursuit of efficient bifunctional acid/ base organocatalysts. ${ }^{23}$ Sulfonamides were chosen to chaperon 2 -aminoDMAP base as the $\mathrm{H}$-bond donor counterpart, due to their ready availability, modular tunability, and recent successful reports claiming the advantageous case of sulfonamides and sulfinylureas over commonly employed thioureas. ${ }^{24}$ In this regard, 10 examples of 2-aminoDMAP/Sulfonamides $7 \mathbf{a}-\mathbf{j}$ were designed and prepared by following the systematic 
Scheme 2. Formal Synthesis of Johnston's BAM Catalyst

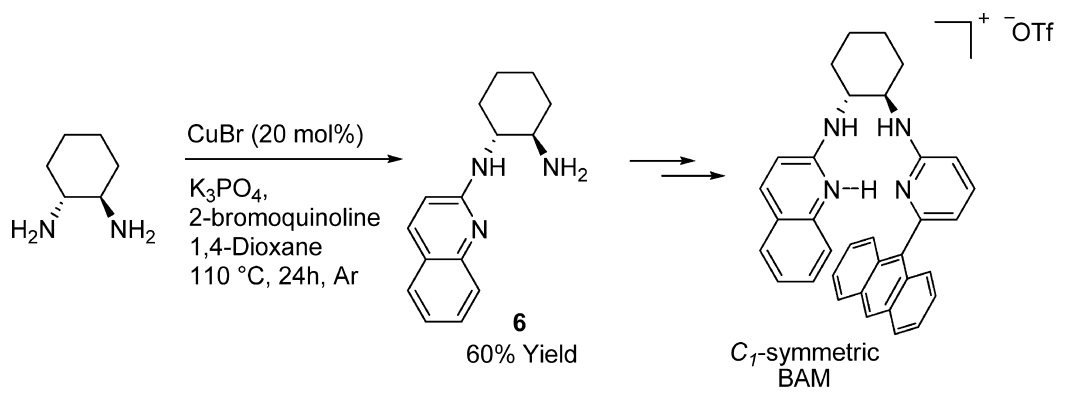

structural elaborations having both steric and electronic bases presented in Scheme 3.

\section{Scheme 3. Systematicity in the Design of 2-AminoDMAP/} Sulfonamides $7 \mathrm{a}-\mathbf{j}$

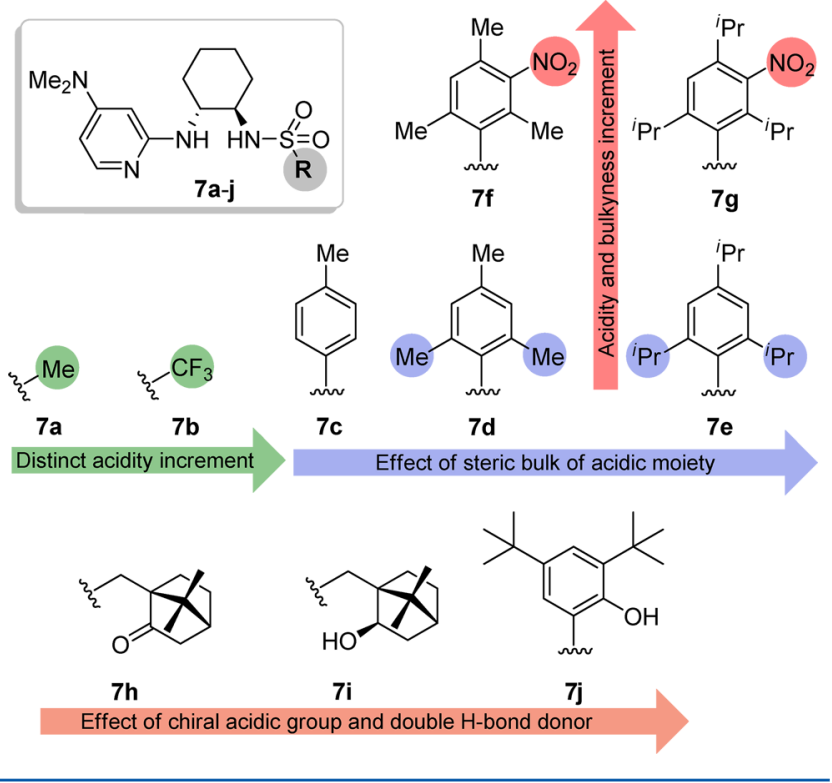

Developed catalysts were screened with the conjugate addition of acetylacetone to trans- $\beta$-nitrostyrene serving as the testing ground for bifunctional organocatalysis (Table $2)^{23,25}$ Distinct acidities of $7 \mathbf{a}$ and $7 \mathbf{b}$ had no impact on enantioselectivity and produced moderate results (entries 1 and 2). Steric demand of catalysts $7 \mathbf{c}-\mathbf{e}$ was clearly observed by a parallel increase in selectivity $(60 \%, 74 \%, 84 \%$ ee's, respectively; entries 3-5). Further, concomitant modulation of steric bulk and acidity was devised by insertion of a nitro group to the meta positions of the best acting candidates $7 \mathbf{d}$ and $7 \mathbf{e}$. Both $7 \mathbf{f}$ and $7 \mathrm{~g}$ were observed to induce slightly higher selectivities (entries 4 and 5 vs entries 6 and 7). Catalysts 7 h and 7i, offered to examine the effect of secondary chirality on the sulfonamide unit, provided low selectivities. Catalyst $7 \mathbf{j}$ bearing an additional phenolic proton gave significantly lower selectivity than all of the other aromatic sulfonamides. Choosing $7 \mathrm{~g}$ as the best catalyst, the effects of solvent, molarity, temperature, and catalyst loading were investigated as well to secure the optimal working condition (entries 11-16). Of the screened solvents, toluene proved to be the best one. ${ }^{17}$ Enantioselectivity decreased at higher concentration $(0.4 \mathrm{M})$ of substrates (entry 11). Almost equal enantioselection ( $89 \%$ ee) was observed at lower concentration $(0.1 \mathrm{M})$; however, reaction
Table 2. Evaluation of 2-AminoDMAP/Sulfonamides $7 \mathrm{a}-\mathrm{j}^{a}$<smiles>O=[N+]([O-])C=Cc1ccccc1</smiles><smiles>CC(=O)CC(C)=O</smiles>

8

9<smiles>CC(=O)C(C(C)=O)C(C[N+](=O)[O-])c1ccccc1</smiles>

10

$\begin{array}{lcccc}\text { entry } & \text { catalyst } & \text { time }(\mathrm{h})^{b} & \text { yield (\%) } & \text { ee (\%) } \\ 1 & 7 \mathbf{a} & 48 & 90 & 62 \\ 2 & 7 \mathbf{b} & 192 & 90 & 61 \\ 3 & 7 \mathbf{c} & 52 & 91 & 60 \\ 4 & 7 \mathbf{d} & 48 & 89 & 74 \\ 5 & 7 \mathbf{e} & 44 & 89 & 84 \\ 6 & 7 \mathbf{f} & 46 & 91 & 76 \\ 7 & 7 \mathbf{g} & 48 & 89 & 88 \\ 8 & 7 \mathbf{h} & 50 & 88 & 28 \\ 9 & 7 \mathbf{i} & 64 & 90 & 50 \\ 10 & 7 \mathbf{j} & 72 & 89 & 57 \\ 11^{c} & 7 \mathbf{g} & 30 & 90 & 82 \\ 12^{d} & 7 \mathbf{g} & 90 & 91 & 89 \\ 13^{e} & 7 \mathbf{g} & 60 & 88 & 90 \\ 14^{f} & 7 \mathbf{g} & 96 & 89 & 92 \\ 15^{f, g} & 7 \mathbf{g} & 144 & 89 & 93 \\ 16^{f, h} & 7 \mathbf{g} & 72 & 89 & 92\end{array}$

${ }^{a}$ Reactions were carried out in $0.2 \mathrm{M}$ concentration of $8 .{ }^{b}$ Time for complete conversion. ${ }^{c} 0.4 \mathrm{M}$ concentration of $8 .{ }^{d} 0.1 \mathrm{M}$ concentration of 8. ${ }^{e}$ Reaction was carried out at $0{ }^{\circ} \mathrm{C}$. ${ }^{f}$ Reaction was carried out at $-10{ }^{\circ}$ C. $g_{5}$ mol \% cat. loading. $h_{20} \mathrm{~mol} \%$ cat. loading.

was sluggish at this time (entry 12). Selectivity was slighty increased upon lowering the temperature to $0{ }^{\circ} \mathrm{C}$ and $-10{ }^{\circ} \mathrm{C}$ ( $90 \%$ and $92 \%$ ee; entries 13 and 14, respectively). It is worthy to note that $7 \mathrm{~g}$ tolerated well $5-20 \mathrm{~mol} \%$ catalyst loadings (entries 15 and 16).

With the optimized reaction condition in hand, the scope of this enantioselective organocatalytic conjugate addition was examined further by varying trans- $\beta$-nitroolefins. All the reactions were conducted in toluene at $0{ }^{\circ} \mathrm{C}$ with $0.2 \mathrm{M}$ concentration of $11 \mathbf{a}-\mathbf{h}$. The results are summarized in Table 3.

Most of the conjugate addition products were obtained in high to excellent yields (87-93\%) and selectivities (75-99\% ee). It is noteworthy that the reaction worked very well with $m$ and $p$-chloro-substituted trans- $\beta$-nitrostyrene derivatives $12 \mathrm{c}$ and $12 \mathrm{~d}$ with $97 \%$ and $99 \%$ ee, respectively. It appears that the electronic nature of the aromatic rings of nitroolefins has little effect on both reaction kinetics and stereoselection.

With these results in hand, a plausible transition state (TS) model was proposed as in Figure 2 to account for the sense of bifunctionality and enantioselectivity brought by $7 \mathrm{~g}$. According 
Table 3. Substrate Scope of trans- $\beta$-Nitroolefins ${ }^{a}$

\begin{tabular}{|c|c|c|c|c|c|}
\hline \multicolumn{2}{|c|}{$11 a-h$} & 9 & $\begin{array}{c}\begin{array}{c}\text { Cat. } 7 \mathrm{~g} \\
(10 \mathrm{~mol} \%)\end{array} \\
\underset{\text { Toluene, } 0{ }^{\circ} \mathrm{C}}{\longrightarrow}\end{array}$ & \multicolumn{2}{|c|}{$12 a-h$} \\
\hline entry & $\mathrm{Ar}$ & product & time $(h)^{b}$ & yield $(\%)^{c}$ & ee $(\%)$ \\
\hline 1 & $2-\mathrm{NO}_{2}-\mathrm{C}_{6} \mathrm{H}_{4}$ & $12 a$ & 58 & 87 & 86 \\
\hline 2 & $2-\mathrm{Cl}-\mathrm{C}_{6} \mathrm{H}_{4}$ & $12 b$ & 60 & 91 & 75 \\
\hline 3 & $3-\mathrm{Cl}-\mathrm{C}_{6} \mathrm{H}_{4}$ & $12 \mathrm{c}$ & 60 & 88 & 97 \\
\hline 4 & 4-Cl- $\mathrm{C}_{6} \mathrm{H}_{4}$ & $12 d$ & 60 & 93 & 99 \\
\hline 5 & 2-thienyl & $12 \mathrm{e}$ & 70 & 76 & 85 \\
\hline 6 & 2-furyl & $12 \mathrm{f}$ & 72 & 91 & 96 \\
\hline 7 & $4-\mathrm{BnO}-\mathrm{C}_{6} \mathrm{H}_{4}$ & $12 \mathrm{~g}$ & 70 & 91 & 93 \\
\hline 8 & $2-\mathrm{MeO}-\mathrm{C}_{6} \mathrm{H}_{4}$ & $12 \mathrm{~h}$ & 65 & 90 & 90 \\
\hline
\end{tabular}

${ }^{a}$ Reactions were carried out in $0.2 \mathrm{M}$ concentration of $11 \mathbf{a}-\mathbf{h} .{ }^{b}$ Time for complete conversion. ${ }^{c}$ Isolated chemical yields.

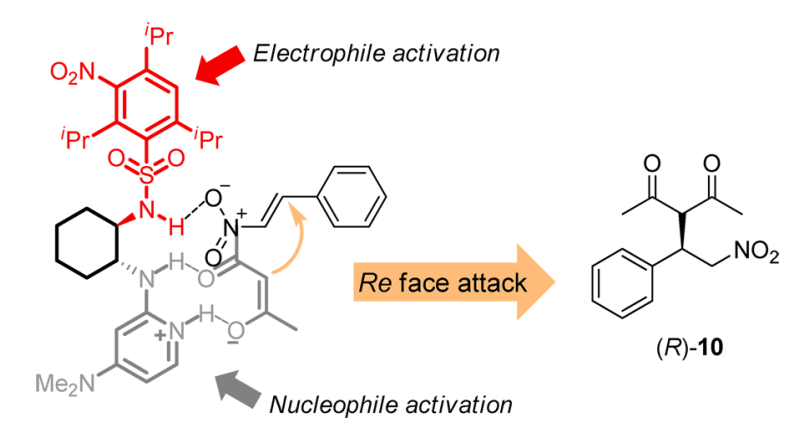

Figure 2. Plausible TS model-bifunctional activation mode.

to this model, - $\mathrm{NH}$ of sulfonamide unit was be responsible for acceptor alkene activation through hydrogen bonding with the nitro group. ${ }^{24 \mathrm{~b}, \mathrm{c}}$ For nucleophile activation, we propose two hydrogen bonding sites available between 2-aminoDMAP unit and the dicarbonyl after partial deprotonation.

\section{CONCLUSIONS}

To sum up, we have described successful direct and selective mono- $N$-pyridylation of trans-cyclohexane-1,2-diamine for the first time. Our $\mathrm{C}-\mathrm{N}$ bond-forming protocol was found to reduce the number of steps involved in the synthesis of Johnston's elegant BAM catalyst dramatically. Transforming trans-cyclohexane-1,2-diamine to its monoamidine in one straightforward step as in our present study would outpace the protective $\mathrm{C}-\mathrm{N}$ coupling strategies applied so far to that end, at least partly due to time and cost effectiveness. Systematically tuned catalyst $7 \mathbf{g}$ was shown to promote the conjugate addition reaction of acetylacetone and various nitroolefins very effectively with good to excellent yields (87-93\%) and with enantioselectivites up to 99\%. Judicious incorporation of novel $\mathrm{H}$-bond donors to the chiral 2aminoDMAP 1 developed herein may give birth to more practical and fruitful organocatalyst libraries for any asymmetric reaction of interest. Current investigations directed along these lines are in progress.

\section{EXPERIMENTAL SECTION}

${ }^{1} \mathrm{H}$ NMR and ${ }^{13} \mathrm{C}$ NMR spectra were recorded on a 400 spectrophotometer using $\mathrm{CDCl}_{3}, \mathrm{CCl}_{4}$, or $d_{6}$-DMSO as the solvent. Chemical shifts values are reported in ppm from tetramethylsilane, and
$J$ values are given in hertz. Spin multiplicities are reported as the following: s (singlet), bs (broad singlet), d (doublet), dd (doublet of doublet), ddd (doublet of doublet of doublet), dt (doublet of triplet), $\mathrm{dq}$ (doublet of quartet), $\mathrm{t}$ (triplet), $\mathrm{q}$ (quartet), sept (septet), $\mathrm{m}$ (multiplet). Polarimetric measurements were made by the use of a polarimeter and reported as follows $[\alpha]_{\mathrm{D}}^{31}(c$ in g per $100 \mathrm{~mL}$, solvent). Enantiomeric excess (ee) values of chiral adducts were detected by a HPLC system using Daicell AS-H chiral column $(0.46 \mathrm{~cm} \phi \times 25 \mathrm{~cm})$, $\mathrm{AD}-\mathrm{H}$ chiral column $(0.4 \mathrm{~cm} \phi \times 10 \mathrm{~cm})$, and IA chiral column $(0.46$ $\mathrm{cm} \phi \times 25 \mathrm{~cm}$ ). HRMS data were acquired on a time of flight (TOF) mass spectrometer. IR spectra of all new compounds were obtained by an IR spectrometer. Flash column chromatography (FCC) was performed by using glass columns with a flash grade silica gel (230400 mesh). Reactions were monitored by thin layer chromatography (TLC) using precoated silica gel plates, visualized by UV light and $p$ anisaldehyde, ninhydrin, and potassium permanganate stains as appropriate. All organic extracts were dehydrated over oven-dried $\mathrm{MgSO}_{4}$ or $\mathrm{K}_{2} \mathrm{CO}_{3}$ and concentrated by using a rotary evaporator before being subjected to FCC.

General Procedure for Cu-Catalyzed C-N Coupling Reactions. An oven-dried resealable Schlenk tube was charged with $\mathrm{CuBr}$ $(29 \mathrm{mg}, 0.2 \mathrm{mmol})$ and $\mathrm{K}_{3} \mathrm{PO}_{4}(424 \mathrm{mg}, 2.0 \mathrm{mmol})$, evacuated, and backfilled with argon thrice. $(R, R)$-Cyclohexane-1,2-diamine $(137 \mathrm{mg}$, $1.20 \mathrm{mmol}$ ), 2-bromoDMAP (201 $\mathrm{mg}, 1.0 \mathrm{mmol}$ ) or 2-bromoquinoline $(208 \mathrm{mg}, 1.0 \mathrm{mmol})$, and dioxane that was distilled over $\mathrm{Na}$ benzophenone under Ar atmosphere $(1.0 \mathrm{~mL})$ were added by Schlenk line. The Schlenk tube was sealed, and the reaction mixture was stirred at $110^{\circ} \mathrm{C}$ for $24 \mathrm{~h}$. The resulting green-blue suspension was allowed to reach room temperature. Then $2 \mathrm{~mL}$ of water and $2 \mathrm{~mL}$ of conc ammonia were added consecutively. The resulting Prussian blue solution was extracted with dichloromethane thrice $(3 \times 25 \mathrm{~mL})$. The combined dichloromethane phase was dried with brine and $\mathrm{MgSO}_{4}$, respectively. The filtrate was concentrated, and the residue was purified by flash chromatography on silica gel using dichloromethane that was saturated with conc aqueous ammonia to afford compounds 1 and $\mathbf{6}$ as pale brown solids.

Data for 1 . Tan brown solid, $140 \mathrm{mg}, 60 \%$ yield. $\mathrm{Mp}: 138-140{ }^{\circ} \mathrm{C}$. $[\alpha]_{\mathrm{D}}^{31}=-55.0\left(c 0.25, \mathrm{CH}_{2} \mathrm{Cl}_{2}\right) .{ }^{1} \mathrm{H}$ NMR $\left(400 \mathrm{MHz}, \mathrm{CDCl}_{3}\right) \delta 0.93-$ $1.09(\mathrm{~m}, 1 \mathrm{H}), 1.09-1.43(\mathrm{~m}, 3 \mathrm{H}), 1.65(\mathrm{dd}, J=2.5,10.0 \mathrm{~Hz}, 2 \mathrm{H})$, $1.75(\mathrm{bs}, 2 \mathrm{H}), 1.85-1.95(\mathrm{~m}, 1 \mathrm{H}), 1.97-2.07(\mathrm{~m}, 1 \mathrm{H}), 2.41(\mathrm{dt}, J=$ 4.1, $10.4 \mathrm{~Hz}, 1 \mathrm{H}), 2.87(\mathrm{~s}, 6 \mathrm{H}), 3.24(\mathrm{dq}, J=4.0,9.6 \mathrm{~Hz}, 1 \mathrm{H}), 4.15(\mathrm{~d}$ $J=9.5 \mathrm{~Hz}, 1 \mathrm{H}), 5.53(\mathrm{~d}, J=2.2 \mathrm{~Hz}, 1 \mathrm{H}), 5.91(\mathrm{dd} J=2.3,6.1 \mathrm{~Hz}$, $1 \mathrm{H}), 7.69(\mathrm{~d}, J=6.1 \mathrm{~Hz}, 1 \mathrm{H}) .{ }^{13} \mathrm{C} \mathrm{NMR}\left(100.6 \mathrm{MHz}, \mathrm{CDCl}_{3}\right) \delta 25.1$, 25.4, 32.9, 34.9, 39.2, 56.3, 58.4, 87.8, 99.2, 148.0, 156.1, 160.1. IR (neat) 3321, 3254, 2922, 2854, 1599, 1527, 1495, 1444, 1265, 1145, 979, 964, 804. HRMS (ESI) calcd for $\mathrm{C}_{13} \mathrm{H}_{23} \mathrm{~N}_{4}[\mathrm{M}+\mathrm{H}]^{+}$235.1923, found 235.1918.

Data for 6. Tan brown solid, $144 \mathrm{mg}, 60 \%$ yield. ${ }^{1} \mathrm{H}$ NMR (400 $\left.\mathrm{MHz}, \mathrm{CDCl}_{3}\right) \delta 0.98-1.11(\mathrm{~m}, 1 \mathrm{H}), 1.12-1.37(\mathrm{~m}, 3 \mathrm{H}), 1.63(\mathrm{dd}, J=$ $3.7,10.0 \mathrm{~Hz}, 2 \mathrm{H}), 1.79-2.12(\mathrm{~m}, 4 \mathrm{H}), 2.43(\mathrm{td}, J=4.0,10.1 \mathrm{~Hz}, 1 \mathrm{H})$, $3.64(\mathrm{bs}, 1 \mathrm{H}), 4.83(\mathrm{bs}, 1 \mathrm{H}), 6.59(\mathrm{~d}, J=8.9 \mathrm{~Hz}, 1 \mathrm{H}), 7.06-7.12(\mathrm{~m}$, $1 \mathrm{H}), 7.41$ (ddd, $J=1.5,7.0,8.4 \mathrm{~Hz}, 1 \mathrm{H}), 7.44-7.48(\mathrm{~m}, 1 \mathrm{H}), 7.54(\mathrm{t}, J$ $=10.3 \mathrm{~Hz}, 1 \mathrm{H}), 7.68(\mathrm{~d}, J=8.9 \mathrm{~Hz}, 1 \mathrm{H}) .{ }^{13} \mathrm{C}$ NMR $(100.6 \mathrm{MHz}$, $\left.70: 30 \mathrm{CDCl}_{3}: \mathrm{CCl}_{4}\right) \delta 25.1,25.3,32.9,35.3,56.3,57.5,111.6,121.9$, $123.5,126.2,127.3,129.5,137.2,148.0,157.2$. HRMS (ESI) calcd for $\mathrm{C}_{15} \mathrm{H}_{20} \mathrm{~N}_{3}[\mathrm{M}+\mathrm{H}]^{+}$242.1657, found 242.1614.

General Procedure for Buchwald-Hartwig C-N Coupling Reactions. In a Schlenk flask, $(1 R, 2 R)$-cyclohexane-1,2-diamine or mono- $N$-protected amine (1 mmol), 2-haloDMAP (2a,b) $(1 \mathrm{mmol})$, base $(1.5 \mathrm{mmol})$, bisphosphine ligand $(0.15 \mathrm{mmol})$, and Pd complex $(0.075 \mathrm{mmol})$ were mixed, and $8 \mathrm{~mL}$ of toluene (distilled over $\mathrm{Na}$ benzophenone under Ar atmosphere) was added under $\mathrm{Ar}$ atm. The resulting mixture was refluxed for $60 \mathrm{~h}$. At the end of the reaction, the mixture was cooled to $\mathrm{rt}$ and transferred to a separatory funnel. The organic phase was washed with $10 \mathrm{~mL}$ of water, and the separated organic phase was dried over $\mathrm{MgSO}_{4}$ and filtered. The filtrate was concentrated under vacuum. The dark residue was purified with flash chromatography using 98:2 EtOAc/TEA (see "Table for BuchwaldHartwig C-N Coupling Reactions" in Supporting Information). 
Data for 14. In a Schlenk flask, mono- $N$-phthalolyl protected amine $13^{26}$ (489 mg, $2 \mathrm{mmol}$ ), 2-bromoDMAP (402 mg, $2 \mathrm{mmol}$ ), $\mathrm{Cs}_{2} \mathrm{CO}_{3}(978 \mathrm{mg}, 3 \mathrm{mmol})$, BINAP $(280 \mathrm{mg}, 0.30 \mathrm{mmol})$, and $\mathrm{Pd}(\mathrm{OAc})_{2}(34 \mathrm{mg}, 0.15 \mathrm{mmol})$ were mixed, and $15 \mathrm{~mL}$ of toluene (distilled over Na-benzophenone under Ar atmosphere) was added under $\mathrm{Ar}$ atm. The resulting mixture was refluxed for $60 \mathrm{~h}$. At the end of the reaction, the mixture was cooled to rt and transferred to a separatory funnel. The organic phase was washed with $20 \mathrm{~mL}$ of water, and the separated organic phase was dried with $\mathrm{MgSO}_{4}$ and filtered. The filtrate was concentrated under vacuum. The dark residue was purified with flash chromatography using 98:2 EtOAc/TEA. As a result, product 14 was obtained as a pale yellow solid $(109 \mathrm{mg}, 15 \%$ yield). Mp: $196-201{ }^{\circ} \mathrm{C} .{ }^{1} \mathrm{H}$ NMR $\left(400 \mathrm{MHz}, \mathrm{CDCl}_{3}\right) \delta 1.08-1.26$ (m, $2 \mathrm{H}), 1.26-1.36(\mathrm{~m}, 1 \mathrm{H}), 1.37-1.51(\mathrm{~m}, 1 \mathrm{H}), 1.69-1.86(\mathrm{~m}, 3 \mathrm{H})$, $2.24-2.13(\mathrm{~m}, 1 \mathrm{H}), 2.41(\mathrm{qd}, J=32,9 \mathrm{~Hz}, 1 \mathrm{H}), 2.75(\mathrm{~s}, 6 \mathrm{H}), 3.93(\mathrm{~d}$, $J=9.4 \mathrm{~Hz}, 1 \mathrm{H}), 4.27(\mathrm{qd}, J=10.9,4.1 \mathrm{~Hz}, 1 \mathrm{H}), 5.38(\mathrm{~d}, J=2.1 \mathrm{~Hz}$, $1 \mathrm{H}), 5.56(\mathrm{dd}, J=6.1,2.2 \mathrm{~Hz}, 1 \mathrm{H}), 7.41(\mathrm{~d}, J=6.1 \mathrm{~Hz}, 1 \mathrm{H}), 7.50(\mathrm{dd}$, $J=5.5,3.0 \mathrm{~Hz}, 2 \mathrm{H}), 7.59(\mathrm{dd}, J=5.5,3.0 \mathrm{~Hz}, 2 \mathrm{H}) .{ }^{13} \mathrm{C} \mathrm{NMR}(100.6$ $\left.\mathrm{MHz}, \mathrm{CDCl}_{3}\right) \delta 25.1,25.6,29.3,34.0,39.1,52.2,56.2$, 88.0, 98.9, $122.8,131.9,133.4,147.9,155.7,159.4,168.9$. HRMS (ESI) calcd for $\mathrm{C}_{21} \mathrm{H}_{25} \mathrm{~N}_{4} \mathrm{O}_{2}[\mathrm{M}+\mathrm{H}]^{+}$365.1978, found 365.1965.

Preparation of 1 via Hydrazine-Mediated Cleavage of 14. Compound 14 (94 mg, $0.25 \mathrm{mmol}$ ) was dissolved in $0.5 \mathrm{~mL}$ of absolute ethanol, hydrazine hydrate $(30 \mu \mathrm{L})$ was added, and the mixture heated to reflux for $2 \mathrm{~h}$. After cooling to $\mathrm{rt}$, ethanol was removed under high vacuum to afford a solid residue. The resulting crude mixture was dissolved in $0.5 \mathrm{~mL}$ of dichloromethane and subjected to flash column chromatography using dichloromethane saturated with aqueous ammonia to afford the product $\mathbf{1}$ as a tan brown solid (53 mg, 90\% yield). (Identical analytical data were obtained.)

Preparation of 2,4,6-Trimethyl-3-nitrobenzene-1-sulfonyl Chloride. To the solid 2,4,6-trimethylbenzene-1-sulfonyl chloride (437 mg, $2 \mathrm{mmol}$ ) was added $1 \mathrm{~mL}$ of fuming nitric acid dropwise in 1 min. The resulting brown solution was stirred $1 \mathrm{~h}$ at $\mathrm{rt}$. It was then diluted with $10 \mathrm{~mL}$ of ice-cold water; a yellow solid precipitation was observed. This mixture was extracted with ether $(25 \mathrm{~mL})$ twice. The obtained organic phase was dried over potassium carbonate and filtered. The organic filtrate was concentrated under vacuum, and product was recrystallized from $n$-pentane to give 2,4,6-trimethyl-3nitrobenzene-1-sulfonyl chloride as pale yellow needles $(517 \mathrm{mg}, 98 \%$ yield). Mp: $60-61{ }^{\circ} \mathrm{C} .{ }^{1} \mathrm{H}$ NMR $\left(400 \mathrm{MHz}, \mathrm{CDCl}_{3}\right) \delta 2.35(\mathrm{~s}, 3 \mathrm{H})$, $2.65(\mathrm{~s}, 3 \mathrm{H}), 2.78(\mathrm{~s}, 3 \mathrm{H}), 7.23(\mathrm{~s}, 1 \mathrm{H}) .{ }^{13} \mathrm{C}$ NMR $(100.6 \mathrm{MHz}$, $\left.\mathrm{CDCl}_{3}\right) \delta 16.4,17.6,23.2,131.0,134.0,135.9,141.3,152.3$. IR (neat) 3648, 2987, 2884, 1594, 1525, 1442, 1372, 1363, 1177, 843, 671, 599. HRMS (ESI) calcd for $\mathrm{C}_{9} \mathrm{H}_{11} \mathrm{~N}_{2} \mathrm{O}_{4} \mathrm{~S}[\mathrm{M}-\mathrm{H}]^{-}$243.0440, found 243.0454. Due to ambiguity in HRMS analysis of the parent compound, it was converted to the corresponding sulfonamide by the following procedure: A $20 \mathrm{~mL}$ 1:1 DCM/ammonia (conc) solution of 2,4,6-trimethyl-3-nitrobenzene-1-sulfonyl chloride (263 $\mathrm{mg}, 1 \mathrm{mmol}$ ) was vigorously stirred at $\mathrm{rt}$ for $2 \mathrm{~h}$. The DCM phase was dried over potassium carbonate, and the filtrate was concentrated under vacuum. The corresponding sulfonamide product was characterized by HRMS analysis without further purification.

Preparation of 2,4,6-Triisopropyl-3-nitrobenzene-1-sulfonyl Chloride. To the solid 2,4,6-triisopropylbenzene-1-sulfonyl chloride (606 $\mathrm{mg}, 2 \mathrm{mmol}$ ) was added $2 \mathrm{~mL}$ of fuming nitric acid dropwise in 1 $\mathrm{min}$. The resulting brown heterogeneous mixture was stirred for $5 \mathrm{~h}$ in a water bath at $40^{\circ} \mathrm{C}$. It was then diluted with $20 \mathrm{~mL}$ of ice-cold water. As a result, a yellow solid was precipitated out. This mixture was extracted with ether $(25 \mathrm{~mL})$ twice. The obtained organic phase was dried over potassium carbonate and filtered. The organic filtrate was concentrated under vacuum. Product was chromatographed on a silica gel column using 20:1 n-hexane/EtOAc to give 2,4,6-triisopropyl-3nitrobenzene-1-sulfonyl chloride as a pale yellow solid (626 mg, 90\% yield). Mp: $149-151^{\circ} \mathrm{C} .{ }^{1} \mathrm{H}$ NMR $\left(400 \mathrm{MHz}, \mathrm{CDCl}_{3}\right) \delta 1.20$ (d, $J=$ $6.8 \mathrm{~Hz}, 6 \mathrm{H}), 1.26(\mathrm{~d}, J=6.7 \mathrm{~Hz}, 6 \mathrm{H}), 1.30(\mathrm{~d}, J=7.1 \mathrm{~Hz}, 6 \mathrm{H}), 2.68$ (sept, $J=6.8 \mathrm{~Hz}, 1 \mathrm{H}), 4.18(\mathrm{sept}, J=6.8 \mathrm{~Hz}, 1 \mathrm{H}), 4.33$ (bs, $1 \mathrm{H}), 7.42$ $(\mathrm{s}, 1 \mathrm{H}) .{ }^{13} \mathrm{C}$ NMR $\left(100.6 \mathrm{MHz}, \mathrm{CDCl}_{3}\right) \delta 21.3,23.6,24.3,29.6,30.7$, 125.6, 139.5, 141.5, 147.1, 150.0, 153.1. IR (neat) 2974, 2925, 2872,
$2854,1728,1529,1584,1455,1392,1368,1361,1173,1112,563$. HRMS (ESI) calcd for $\mathrm{C}_{15} \mathrm{H}_{23} \mathrm{~N}_{2} \mathrm{O}_{4} \mathrm{~S}[\mathrm{M}-\mathrm{H}]^{-} 327.1379$, found 327.1402. Due to ambiguity in HRMS analysis of the parent compound, it was converted to the corresponding sulfonamide by following procedure: A $20 \mathrm{~mL}$ 1:1 DCM/ammonia (conc) solution of 2,4,6-triisopropyl-3-nitrobenzene-1-sulfonyl chloride (348 mg, 1 $\mathrm{mmol}$ ) was vigorously stirred at $\mathrm{rt}$ for $2 \mathrm{~h}$. The DCM phase was dried over potassium carbonate, and the filtrate was concentrated under vacuum. Corresponding sulfonamide product was characterized by HRMS analysis without further purification.

General Procedure for the Preparation of 2-AminoDMAP/ Sulfonamides $7 \mathrm{a}-\mathbf{j}$. To a solution of $(R, R)$ 2-aminoDMAP 1 (47 $\mathrm{mg}, 0.2 \mathrm{mmol})$ and triethylamine $(22.2 \mathrm{mg}, 30 \mu \mathrm{L}, 0.22 \mathrm{mmol})$ in $\mathrm{CH}_{2} \mathrm{Cl}_{2}(1 \mathrm{~mL})$ was added sulfonyl chloride $(0.2 \mathrm{mmol}$ as solid or liquid) at $0{ }^{\circ} \mathrm{C}$. The mixture was brought to room temperature and stirred for $1 \mathrm{~h}$. The mixture was directly loaded on to a silica gel column and eluted with EtOAc/TEA (98:2) to afford 2-aminoDMAP/ sulfonamides $7 \mathbf{a}-\mathbf{j}(60-96 \%$ yield) as solid.

Data for 7a. Colorless amorphous solid, $57 \mathrm{mg}$, 92\% yield. Mp: $183-186{ }^{\circ} \mathrm{C} .[\alpha]_{\mathrm{D}}^{31}=+4.7\left(\right.$ c $\left.0.25, \mathrm{CH}_{2} \mathrm{Cl}_{2}\right) .{ }^{1} \mathrm{H}$ NMR $(400 \mathrm{MHz}$, $\left.\mathrm{CDCl}_{3}\right) \delta 1.16-1.52(\mathrm{~m}, 4 \mathrm{H}), 1.73(\mathrm{~m}, 2 \mathrm{H}), 1.96-2.07(\mathrm{~m}, 1 \mathrm{H})$, 2.14-2.28 (m, 1H), $2.67(\mathrm{~s}, 3 \mathrm{H}), 2.94(\mathrm{~s}, 6 \mathrm{H}), 2.92-2.98(\mathrm{~m}, 1 \mathrm{H})$, $3.74-3.55(\mathrm{~m}, 1 \mathrm{H}), 4.28(\mathrm{~d}, J=5.4 \mathrm{~Hz}, 1 \mathrm{H}), 5.59(\mathrm{~d}, J=2.2 \mathrm{~Hz}, 1 \mathrm{H})$, $6.02(\mathrm{dd}, J=2.3,6.2 \mathrm{~Hz}, 1 \mathrm{H}), 7.72(\mathrm{~d}, J 6.2 \mathrm{~Hz}, 1 \mathrm{H}) ; 1$ exchangeable sulfonamide $\mathrm{H}$ not located. ${ }^{13} \mathrm{C} \mathrm{NMR}\left(100.6 \mathrm{MHz}, \mathrm{CDCl}_{3}\right) \delta 24.4$, 25.1, 33.4, 35.2, 39.2 (2C), 54.6, 62.2, 89.0, 100.2, 146.9, 156, 159.7. IR (neat) 3376, 2921, 2854, 1608, 1530, 1495, 1444, 1259, 1016, 793. HRMS (ESI) calcd for $\mathrm{C}_{14} \mathrm{H}_{25} \mathrm{~N}_{4} \mathrm{O}_{2} \mathrm{~S}[\mathrm{M}+\mathrm{H}]^{+} 313.1698$, found 313.1688 .

Data for $7 \mathrm{~b}$. This reaction was carried out at $-20{ }^{\circ} \mathrm{C}$, and triflic anhydride was added dropwise over $2 \mathrm{~min}$. Amorphous off-white solid $44 \mathrm{mg}, 60 \%$ yield. Mp: $230-235{ }^{\circ} \mathrm{C}$. $[\alpha]_{\mathrm{D}}^{31}=+14.1\left(\right.$ c $\left.0.25, \mathrm{CH}_{2} \mathrm{Cl}_{2}\right)$. ${ }^{1} \mathrm{H}$ NMR (400 MHz, $d_{6}$-DMSO) $\delta 1.12-1.43(\mathrm{~m}, 4 \mathrm{H}), 1.55-1.73(\mathrm{~m}$, $2 \mathrm{H}), 1.85-2.02(\mathrm{~m}, 2 \mathrm{H}), 2.97(\mathrm{~s}, 6 \mathrm{H}), 3.08-2.94(\mathrm{~m}, 1 \mathrm{H}), 5.81(\mathrm{~d}, J$ $=2.3 \mathrm{~Hz}, 1 \mathrm{H}), 6.23(\mathrm{dd}, J=2.4,6.9 \mathrm{~Hz}, 1 \mathrm{H}), 6.72(\mathrm{~d}, J=5.9 \mathrm{~Hz}, 1 \mathrm{H})$, $7.56(\mathrm{~d}, J=6.9 \mathrm{~Hz}, 1 \mathrm{H}) .{ }^{13} \mathrm{C}$ NMR $\left(100.6 \mathrm{MHz}, d_{6}\right.$-DMSO) $\delta 23.9$, 24.3, 31.8, 34.4, 39.0, 57.4, 60.8, 88.0, 99.9, 116.1, 119.4, 122.6, 125.9, $139.6,155.98,156.17$. IR (neat) $3342,3111,2926,2849,2458,2108$, $1651,1724,1523,1372,1204,1173,1142,1085,831,792,594$. HRMS (ESI) calcd for $\mathrm{C}_{14} \mathrm{H}_{22} \mathrm{~F}_{3} \mathrm{~N}_{4} \mathrm{O}_{2} \mathrm{~S}[\mathrm{M}+\mathrm{H}]^{+} 367.1404$, found 367.1416.

Data for 7c. Colorless amorphous solid, $73 \mathrm{mg}, 94 \%$ yield. Mp: $176-178{ }^{\circ} \mathrm{C} .[\alpha]_{\mathrm{D}}^{31}=+85.7\left(c 0.25, \mathrm{CH}_{2} \mathrm{Cl}_{2}\right) .{ }^{1} \mathrm{H}$ NMR $(400 \mathrm{MHz}$, $\left.\mathrm{CDCl}_{3}\right) \delta 1.05-1.32(\mathrm{~m}, 3 \mathrm{H}), 1.35-1.50(\mathrm{~m}, 1 \mathrm{H}), 1.68(\mathrm{~m}, 2 \mathrm{H}), 1.86$ $(\mathrm{m}, 1 \mathrm{H}), 2.20-2.29(\mathrm{~m}, 1 \mathrm{H}), 2.32(\mathrm{~s}, 3 \mathrm{H}), 2.69(\mathrm{dt}, J=4.2,11.0 \mathrm{~Hz}$, $1 \mathrm{H}), 2.92(\mathrm{~s}, 6 \mathrm{H}), 3.51-3.68(\mathrm{~m}, 1 \mathrm{H}), 3.73(\mathrm{~d}, J=5.2 \mathrm{~Hz}, 1 \mathrm{H}), 5.19$ $(\mathrm{d}, J=2.1 \mathrm{~Hz}, 1 \mathrm{H}), 6.02(\mathrm{dd}, J=2.2,6.2 \mathrm{~Hz}, 1 \mathrm{H}), 7.02(\mathrm{~d}, J=8.0 \mathrm{~Hz}$, $2 \mathrm{H}), 7.34(\mathrm{~d}, J=8.2 \mathrm{~Hz}, 2 \mathrm{H}), 7.73(\mathrm{~d}, J=6.2 \mathrm{~Hz}, 1 \mathrm{H}) ; 1$ exchangeable sulfonamide $\mathrm{H}$ not located. ${ }^{13} \mathrm{C}$ NMR $\left(100.6 \mathrm{MHz} \mathrm{CDCl}_{3}\right) \delta 19.9$ 22.7, 23.4, 31.7, 33.2, 37.6, 52.1, 60.0, 87.8, 98.4, 125.2, 127.4, 136.4, 145.0, 154.2, 157.6. IR (neat) $3421,3065,2942,2921,2854,1605$, 1522, 1489, 1370, 1324, 1295, 1259, 1158, 1089, 799, 660, 567. HRMS (ESI) calcd for $\mathrm{C}_{20} \mathrm{H}_{29} \mathrm{~N}_{4} \mathrm{O}_{2} \mathrm{~S}[\mathrm{M}+\mathrm{H}]^{+} 389.2011$, found 389.2008.

Data for 7d. Colorless amorphous solid, $77 \mathrm{mg}, 93 \%$ yield. Mp: $190-191{ }^{\circ} \mathrm{C} .[\alpha]_{\mathrm{D}}^{31}=+38.3\left(\right.$ c $\left.0.25, \mathrm{CH}_{2} \mathrm{Cl}_{2}\right) .{ }^{1} \mathrm{H}$ NMR $(400 \mathrm{MHz}$, $\left.\mathrm{CDCl}_{3}\right) \delta 1.07-1.37(\mathrm{~m}, 4 \mathrm{H}), 1.53-1.75(\mathrm{~m}, 2 \mathrm{H}), 1.92-2.00(\mathrm{~m}$, $1 \mathrm{H}), 2.09(\mathrm{~m}, 1 \mathrm{H}), 2.26(\mathrm{~s}, 3 \mathrm{H}), 2.50(\mathrm{~s}, 6 \mathrm{H}), 2.90(\mathrm{~s}, 6 \mathrm{H}), 2.90-3.02$ $(\mathrm{m}, 1 \mathrm{H}), 3.68(\mathrm{~m}, 1 \mathrm{H}), 3.98(\mathrm{~d}, J=6.7 \mathrm{~Hz}, 1 \mathrm{H}), 5.41(\mathrm{~d}, J=2.2 \mathrm{~Hz}$, $1 \mathrm{H}), 5.99(\mathrm{dd}, J=2.2,6.2 \mathrm{~Hz}, 1 \mathrm{H}), 6.85(\mathrm{~s}, 2 \mathrm{H}), 7.68(\mathrm{~d}, J=6.2 \mathrm{~Hz}$, $1 \mathrm{H}) ; 1$ exchangeable sulfonamide $\mathrm{H}$ not located. ${ }^{13} \mathrm{C}$ NMR $(100.6$ $\left.\mathrm{MHz}, \mathrm{CDCl}_{3}\right) \delta 20.9,22.9,24.4,25.0,33.5,33.6,39.2,53.9,60.3,89.2$, 100.1, 131.6, 135.7, 138.8, 141.1, 147.0, 155.9, 159.6. IR (neat) 3413, $3170,2942,2854,1603,1522,1489,1445,1325,1297,1287,1158$, $1145,1071,800,659$. HRMS (ESI) calcd for $\mathrm{C}_{22} \mathrm{H}_{33} \mathrm{~N}_{4} \mathrm{O}_{2} \mathrm{~S}[\mathrm{M}+\mathrm{H}]^{+}$ 417.2324, found 417.2325.

Data for 7e. Colorless amorphous solid, $90 \mathrm{mg}, 90 \%$ yield. Mp: $186-187^{\circ} \mathrm{C} .[\alpha]_{\mathrm{D}}^{31}=+69.8\left(c 0.25, \mathrm{CH}_{2} \mathrm{Cl}_{2}\right) .{ }^{1} \mathrm{H}$ NMR $(400 \mathrm{MHz}$, $\left.\mathrm{CDCl}_{3}\right) \delta 1.19(\mathrm{~d}, J=6.7 \mathrm{~Hz}, 6 \mathrm{H}), 1.24(\mathrm{~d}, J=7.0 \mathrm{~Hz}, 12 \mathrm{H}), 1.25-$ $1.36(\mathrm{~m}, 4 \mathrm{H}), 1.59(\mathrm{~m}, 1 \mathrm{H}), 1.69(\mathrm{~m}, 1 \mathrm{H}), 1.94-2.10(\mathrm{~m}, 2 \mathrm{H}), 2.89$ $(\mathrm{s}, 6 \mathrm{H}), 2.83-2.93(\mathrm{~m}, 1 \mathrm{H}), 3.19(\mathrm{dt}, J=3.9,10.4 \mathrm{~Hz}, 1 \mathrm{H}), 3.60-3.74$ (m, 1H), 4.12 (sept, $J=7.2 \mathrm{~Hz}, 1 \mathrm{H}), 4.16$ (sept, $J=6.4 \mathrm{~Hz}, 2 \mathrm{H}), 4.27$ 
$(\mathrm{d}, J=5.8 \mathrm{~Hz}, 1 \mathrm{H}), 5.56(\mathrm{~d}, J=2.2 \mathrm{~Hz}, 1 \mathrm{H}), 5.99(\mathrm{dd}, J=2.2,6.2 \mathrm{~Hz}$, $1 \mathrm{H}), 7.10(\mathrm{~s}, 2 \mathrm{H}), 7.66(\mathrm{~d}, J=6.2 \mathrm{~Hz}, 1 \mathrm{H}) ;{ }^{13} \mathrm{C} \mathrm{NMR}(100.6 \mathrm{MHz}$, $\left.\mathrm{CDCl}_{3}\right) \delta 23.6,24.3,24.8,25.0,29.6,33.3,33.4,34.0,39.2,54.6,59.6$, 89.6, 100.1, 123.5, 135.0, 146.6, 149.9, 151.8, 155.9, 159.6. IR (neat) 3373, 2954, 2927, 2864, 1607, 1457, 1290, 1145. HRMS (ESI) calcd for $\mathrm{C}_{28} \mathrm{H}_{45} \mathrm{~N}_{4} \mathrm{O}_{2} \mathrm{~S}[\mathrm{M}+\mathrm{H}]^{+}$501.3263, found 501.3273.

Data for 7f. Yellow amorphous solid, $88 \mathrm{mg}$, $96 \%$ yield. Mp: $181-$ $184{ }^{\circ} \mathrm{C} .[\alpha]_{\mathrm{D}}^{31}=+43.2\left(\right.$ c $\left.0.25, \mathrm{CH}_{2} \mathrm{Cl}_{2}\right) .{ }^{1} \mathrm{H}$ NMR $\left(400 \mathrm{MHz}, \mathrm{CDCl}_{3}\right)$ $\delta 1.09-1.41(\mathrm{~m}, 4 \mathrm{H}), 1.58-1.79(\mathrm{~m}, 2 \mathrm{H}), 1.88-1.97(\mathrm{~m}, 1 \mathrm{H}), 2.12-$ $2.20(\mathrm{~m}, 1 \mathrm{H}), 2.23(\mathrm{~s}, 3 \mathrm{H}), 2.30(\mathrm{~s}, 3 \mathrm{H}), 2.59(\mathrm{~s}, 3 \mathrm{H}), 2.86-2.96(\mathrm{~m}$, $1 \mathrm{H}), 2.93(\mathrm{~s}, 6 \mathrm{H}), 3.54-3.77(\mathrm{~m}, 1 \mathrm{H}), 3.91(\mathrm{bs}, 1 \mathrm{H}), 5.42(\mathrm{~d}, J=2.2$ $\mathrm{Hz}, 1 \mathrm{H}), 6.01(\mathrm{dd}, J=2.2,6.2 \mathrm{~Hz}, 1 \mathrm{H}), 6.98(\mathrm{~s}, 1 \mathrm{H}), 7.64(\mathrm{~d}, J=6.2$ $\mathrm{Hz}, 1 \mathrm{H}) ; 1$ exchangeable sulfonamide $\mathrm{H}$ not located. ${ }^{13} \mathrm{C}$ NMR (100.6 $\left.\mathrm{MHz}, \mathrm{CDCl}_{3}\right) \delta 15.7,17.1,23.7,24.4,25.1,33.5,33.9,39.2,54.2$, $61.40,89.0,100.4,129.9,131.4,133.0,138.1,140.7,146.5,152.4$, 155.9, 159.5. IR (neat) 3403, 3100, 2942, 2866, 1620, 1527, 1491, $1447,1371,1326,1298,1161,1095,842,612$. HRMS (ESI) calcd for $\mathrm{C}_{22} \mathrm{H}_{32} \mathrm{~N}_{5} \mathrm{O}_{4} \mathrm{~S}[\mathrm{M}+\mathrm{H}]^{+}$462.2175, found 462.2159.

Data for $7 \mathrm{~g}$. Pale yellow fluffy solid, $104 \mathrm{mg}, 96 \%$ yield. Mp: $150-$ $155^{\circ} \mathrm{C} .[\alpha]_{\mathrm{D}}^{31}=+43.2\left(\right.$ c $\left.0.25, \mathrm{CH}_{2} \mathrm{Cl}_{2}\right) .{ }^{1} \mathrm{H}$ NMR $\left(400 \mathrm{MHz}, \mathrm{CDCl}_{3}\right)$ $\delta 1.34-1.06(\mathrm{~m}, 24 \mathrm{H}), 1.56(\mathrm{~d}, J=11.2 \mathrm{~Hz}, 1 \mathrm{H}), 1.66(\mathrm{~d}, J=10.0 \mathrm{~Hz}$, $1 \mathrm{H}), 2.01-1.89(\mathrm{~m}, 2 \mathrm{H}), 2.62$ (sept, $J=6.8 \mathrm{~Hz}, 1 \mathrm{H}), 2.85(\mathrm{~s}, 6 \mathrm{H})$, $3.14(\mathrm{dt}, J=3.9,10.7 \mathrm{~Hz}, 1 \mathrm{H}), 3.48-3.66(\mathrm{~m}, 1 \mathrm{H}), 3.92-4.18(\mathrm{~m}$, $2 \mathrm{H}), 4.21-4.41(\mathrm{~m}, 1 \mathrm{H}), 5.48(\mathrm{~d}, J=2.1 \mathrm{~Hz}, 1 \mathrm{H}), 5.95(\mathrm{dd}, J=2.3$, $6.3 \mathrm{~Hz}, 1 \mathrm{H}), 7.26(\mathrm{~s}, 1 \mathrm{H}), 7.56(\mathrm{~d}, J=6.2 \mathrm{~Hz}, 1 \mathrm{H}) ; 1$ exchangeable sulfonamide $\mathrm{H}$ not located. ${ }^{13} \mathrm{C} \mathrm{NMR}\left(100.6 \mathrm{MHz}, \mathrm{CDCl}_{3}\right) \delta 21.6$, 21.7, 23.7, 24.1, 24.6, 24.8, 25.1, 28.9, 29.1, 30.5, 33.4, 33.6, 39.2, 55.1, 89.6, 100.5, 124.4, 138.5, 139.0, 143.2, 150.0, 152.4, 156.0. IR (neat) 3377, 2966, 2930, 2860, 1609, 1528, 1447, 1366, 1290, 1157, 1108. HRMS (ESI) calcd for $\mathrm{C}_{28} \mathrm{H}_{44} \mathrm{~N}_{5} \mathrm{O}_{4} \mathrm{~S}[\mathrm{M}+\mathrm{H}]^{+}$546.3114, found 546.3107.

Data for $7 \mathrm{~h}$. White amorphous solid, $83 \mathrm{mg}$, 93\% yield. Mp: $257-$ $258{ }^{\circ} \mathrm{C} .[\alpha]_{\mathrm{D}}^{31}=-4.6\left(c 0.25, \mathrm{CH}_{2} \mathrm{Cl}_{2}\right) .{ }^{1} \mathrm{H} \mathrm{NMR}\left(400 \mathrm{MHz}, \mathrm{CDCl}_{3}\right)$ $\delta 0.61(\mathrm{~s}, 3 \mathrm{H}), 0.93(\mathrm{~s}, 3 \mathrm{H}), 1.53-1.22(\mathrm{~m}, 5 \mathrm{H}), 1.83-1.59(\mathrm{~m}, 3 \mathrm{H})$, $1.88(\mathrm{~d}, J=18.4 \mathrm{~Hz}, 1 \mathrm{H}), 2.10-1.91(\mathrm{~m}, 3 \mathrm{H}), 2.24-2.13(\mathrm{~m}, 2 \mathrm{H})$, $2.29(\mathrm{dt}, J=3.6,18.4 \mathrm{~Hz}, 1 \mathrm{H}), 2.56-2.38(\mathrm{~m}, 1 \mathrm{H}), 2.90(\mathrm{~s}, 6 \mathrm{H}), 3.13$ $(\mathrm{dt}, J=4.2,10.5 \mathrm{~Hz}, 1 \mathrm{H}), 3.58(\mathrm{~d}, J=14.8 \mathrm{~Hz}, 1 \mathrm{H}), 3.73-3.85(\mathrm{~m}$, $1 \mathrm{H}), 4.21(\mathrm{~d}, J=6.3 \mathrm{~Hz}, 1 \mathrm{H}), 5.52(\mathrm{~d}, J=2.2 \mathrm{~Hz}, 1 \mathrm{H}), 6.01(\mathrm{dd}, J=$ 2.3, $6.2 \mathrm{~Hz}, 1 \mathrm{H}), 7.75(\mathrm{~d}, J=6.2 \mathrm{~Hz}, 1 \mathrm{H}), 7.83(\mathrm{bs}, 1 \mathrm{H}) .{ }^{13} \mathrm{C}$ NMR $\left(100.6 \mathrm{MHz}, \mathrm{CDCl}_{3}\right) \delta 19.4,19.9,24.4,24.8,24.9,27.0,33.2,35.2$, $39.2,42.5,42.7,47.8,53.7,58.3,61.8,88.9,100.0,147.2,156.0,159.6$, 215.6. IR (neat) 3358, 2946, 2918, 2854, 1744, 1608, 1526, 1496, 1321, 1290, 1090, 807, 793. HRMS (ESI) calcd for $\mathrm{C}_{23} \mathrm{H}_{37} \mathrm{~N}_{4} \mathrm{O}_{3} \mathrm{~S}[\mathrm{M}$ $+\mathrm{H}]^{+} 449.2586$, found 449.2575 .

Data for 7i. This compound was prepared by the following procedure: Compound 2-aminoDMAP/sulfonamide $7 \mathbf{h}(90 \mathrm{mg}, 0.2$ mmol) was dissolved in ethanol $(2.5 \mathrm{~mL})$ and treated with $\mathrm{NaBH}_{4}(45$ $\mathrm{mg}, 1.2 \mathrm{mmol}$ ) portionwise at $0{ }^{\circ} \mathrm{C}$. The reaction mixture was warmed to room temperature and stirred for $24 \mathrm{~h}$. After this time, ethanol was removed under reduced pressure, and the resulting residue was dissolved in a saturated solution of $\mathrm{NH}_{4} \mathrm{Cl}(2 \mathrm{~mL})$ and extracted twice with $\mathrm{CH}_{2} \mathrm{Cl}_{2}(2 \times 15 \mathrm{~mL})$. The combined organic layers were washed with brine, dried over anhydrous $\mathrm{MgSO}_{4}$, filtered, and then concentrated. The residue was purified by flash chromatography on silica gel using with EtOAc/TEA (98:2) as the eluant to afford 2aminoDMAP/Sulfonamide $7 \mathbf{i}$ as white amorphous solid $(77 \mathrm{mg}, 85 \%$ yield). Mp: $250-256{ }^{\circ} \mathrm{C}$. $[\alpha]_{\mathrm{D}}^{31}=-32.9\left(\mathrm{c} 0.25, \mathrm{CH}_{2} \mathrm{Cl}_{2}\right) .{ }^{1} \mathrm{H}$ NMR $\left(400 \mathrm{MHz}, \mathrm{CDCl}_{3}\right) \delta 0.51(\mathrm{~s}, 3 \mathrm{H}), 0.98(\mathrm{~s}, 3 \mathrm{H}), 0.99-1.12(\mathrm{~m}, 1 \mathrm{H})$, $1.19-1.41(\mathrm{~m}, 4 \mathrm{H}), 1.41-1.54(\mathrm{~m}, 3 \mathrm{H}), 1.55-1.66(\mathrm{~m}, 2 \mathrm{H}), 1.66-$ $1.83(\mathrm{~m}, 4 \mathrm{H}), 1.99-2.09(\mathrm{~m}, 2 \mathrm{H}), 2.16(\mathrm{~d}, J=12.4 \mathrm{~Hz}, 1 \mathrm{H}), 2.93(\mathrm{~s}$, $6 \mathrm{H}), 3.01(\mathrm{dt}, J=4.0,11.2 \mathrm{~Hz}, 1 \mathrm{H}), 3.42(\mathrm{~d}, J=13.7 \mathrm{~Hz}, 1 \mathrm{H}), 3.71-$ $3.88(\mathrm{~m}, 1 \mathrm{H}), 4.03(\mathrm{dd}, J=4.3,8.0 \mathrm{~Hz}, 1 \mathrm{H}), 4.10-4.25(\mathrm{~m}, 1 \mathrm{H}), 5.53$ $(\mathrm{d}, J=2.2 \mathrm{~Hz}, 1 \mathrm{H}), 6.03(\mathrm{dd}, J=6.2,2.3 \mathrm{~Hz}, 1 \mathrm{H}), 7.74(\mathrm{~d}, J=6.2 \mathrm{~Hz}$, $1 \mathrm{H}) ; 1$ exchangeable sulfonamide $\mathrm{H}$ not located. ${ }^{13} \mathrm{C}$ NMR $(100.6$ $\left.\mathrm{MHz}, \mathrm{CDCl}_{3}\right) \delta 20.0,20.1,24.5,25.0,27.3,30.5,33.4,35.6,38.8,39.1$, 44.3, 48.3, 50.2, 51.0, 53.7, 62.7, 76.4, 88.7, 100.2, 147.0, 156.1, 159.5 . IR (neat) 3381, 3307, 2955, 2924, 2856, 1614, 1530, 1507, 1447, 1311, 1299, 1263, 1173, 1136, 1079, 989, 807. HRMS (ESI) calcd for $\mathrm{C}_{23} \mathrm{H}_{39} \mathrm{~N}_{4} \mathrm{O}_{3} \mathrm{~S}[\mathrm{M}+\mathrm{H}]^{+}$451.2743, found 451.2732.
Data for 7j. Off-white amorphous solid, $72 \mathrm{mg}, 72 \%$ yield. Mp: 140-150 ${ }^{\circ} \mathrm{C}$. $[\alpha]_{\mathrm{D}}^{31}=+98.5\left(c 0.25, \mathrm{CH}_{2} \mathrm{Cl}_{2}\right) .{ }^{1} \mathrm{H}$ NMR $(400 \mathrm{MHz}$, $\left.\mathrm{CDCl}_{3}\right) \delta 1.07(\mathrm{~s}, 9 \mathrm{H}), 1.11-1.20(\mathrm{~m}, 4 \mathrm{H}), 1.28(\mathrm{~s}, 9 \mathrm{H}), 1.62(\mathrm{t}, J=$ $11.7 \mathrm{~Hz}, 2 \mathrm{H}), 1.80-1.88(\mathrm{~m}, 1 \mathrm{H}), 2.20(\mathrm{~d}, J=13.2 \mathrm{~Hz}, 1 \mathrm{H}), 2.72(\mathrm{td}$, $J=11.0,4.1 \mathrm{~Hz}, 1 \mathrm{H}), 2.83(\mathrm{~s}, 6 \mathrm{H}), 3.39-3.50(\mathrm{~m}, 1 \mathrm{H}), 3.71(\mathrm{bs}, 1 \mathrm{H})$, $5.29(\mathrm{~d}, J=2.1 \mathrm{~Hz}, 1 \mathrm{H}), 5.95(\mathrm{dd}, J=2.3,6.3 \mathrm{~Hz}, 1 \mathrm{H}), 7.15(\mathrm{~d}, J=2.4$ $\mathrm{Hz}, 1 \mathrm{H}), 7.29(\mathrm{~d}, J=2.4 \mathrm{~Hz}, 1 \mathrm{H}), 7.67(\mathrm{~d}, J=6.3 \mathrm{~Hz}, 1 \mathrm{H})$. Two exchangeable protons not located. ${ }^{13} \mathrm{C} \mathrm{NMR}\left(100.6 \mathrm{MHz}, \mathrm{CDCl}_{3}\right) \delta$ 24.3, 25.0, 29.5, 31.2, 33.5, 34.0, 34.2, 35.4, 39.1, 55.1, 61.1, 89.4, $100.4,122.2$, 122.8, 128.7, 137.6, 141.1, 146.2, 152.1, 155.98, 156.17. IR (neat) 3381, 3240, 2924, 2855, 1612, 1479, 1529, 1362, 1269, 1184, $1169,1103,698,634,598$. HRMS (ESI) calcd for $\mathrm{C}_{27} \mathrm{H}_{43} \mathrm{~N}_{4} \mathrm{O}_{3} \mathrm{~S}[\mathrm{M}+$ $\mathrm{H}]^{+}$503.3056, found 503.3060.

General Procedure for Asymmetric Michael Addition of Acetylacetone to trans- $\beta$-Nitrostyrenes. To a solution of trans- $\beta$ nitrostyrene 8 or $11 \mathrm{a}-\mathrm{h}(29.8 \mathrm{mg}, 0.20 \mathrm{mmol})$ in toluene $(1.0 \mathrm{~mL})$ were added 2-aminoDMAP/sulfonamide $7 \mathrm{~g}(10.9 \mathrm{mg}, 0.02 \mathrm{mmol})$ and acetylacetone $9(40 \mathrm{mg}, 41 \mu \mathrm{L}, 0.4 \mathrm{mmol})$. Upon consumption of trans- $\beta$-nitrostyrene (monitored by TLC and $p$-anisaldehyde stain), the reaction mixture was directly subjected to flash column chromatography using EtOAc/ $n$-hexanes as the eluant to afford the conjugate addition products 10 and $12 \mathrm{a}-\mathrm{h}$ as colorless solids.

(R)-3-(2-Nitro-1-phenylethyl)pentane-2,4-dione (10). Yield 44 $\mathrm{mg}$, $89 \%$. Analytical data matched previously reported value. ${ }^{25 \mathrm{e}} \mathrm{HPLC}$ (AS-H, 85:15 $n$-hexane/isopropyl alcohol, $1 \mathrm{~mL} / \mathrm{min}, 210 \mathrm{~nm}$,): $t_{\text {major }}$ $=37.2 \mathrm{~min}, t_{\mathrm{minor}}=21.6 \mathrm{~min}, 93 \%$ ee; $[\alpha]_{\mathrm{D}}^{31}=-75.5^{\circ}\left(c 0.25, \mathrm{CH}_{2} \mathrm{Cl}_{2}\right)$.

(R)-3-(2-Nitro-1-(2-nitrophenyl)ethyl)pentane-2,4-dione (12a). Yield $51 \mathrm{mg}, 87 \%$. Analytical data matched previously reported value. ${ }^{25 a}$ HPLC (IA, 90:10 $n$-hexane/isopropyl alcohol, $1 \mathrm{~mL} / \mathrm{min}, 210$ $\mathrm{nm}): t_{\text {major }}=30.8 \mathrm{~min}, t_{\text {minor }}=34.3 \mathrm{~min}, 86 \%$ ee; $[\alpha]_{\mathrm{D}}^{25}=-15.2(c 0.25$, $\left.\mathrm{CHCl}_{3}\right)$.

(R)-3-(1-(2-Chlorophenyl)-2-nitroethyl)pentane-2,4-dione (12b). Yield $52 \mathrm{mg}, 91 \%$. Analytical data matched previously reported value. ${ }^{25 \mathrm{c}}$ HPLC (IA, 90:10 $n$-hexane/isopropyl alcohol, $1 \mathrm{~mL} / \mathrm{min}, 210$ $\mathrm{nm}): t_{\text {major }}=18.0 \mathrm{~min}, t_{\text {minor }}=21.2 \mathrm{~min}, 75 \%$ ee; $[\alpha]_{\mathrm{D}}^{25}=-158.92(c$ $\left.0.5, \mathrm{CHCl}_{3}\right)$.

(R)-3-(1-(3-Chlorophenyl)-2-nitroethyl)pentane-2,4-dione (12c). Yield $50 \mathrm{mg}, 88 \%$. Analytical data matched previously reported value. ${ }^{25 c}$ HPLC (IA, 90:10 $n$-hexane/isopropyl alcohol, $0.6 \mathrm{~mL} / \mathrm{min}$, $210 \mathrm{~nm}): t_{\text {major }}=22.2 \mathrm{~min}, t_{\text {minor }}=23.3 \mathrm{~min}, 97 \%$ ee; $[\alpha]_{\mathrm{D}}^{25}=-45.92$ (c $\left.0.5, \mathrm{CHCl}_{3}\right)$.

(R)-3-(1-(4-Chlorophenyl)-2-nitroethyl)pentane-2,4-dione (12d). Yield $53 \mathrm{mg}, 93 \%$. Analytical data matched previously reported value. ${ }^{25 \mathrm{c}}$ HPLC (IA, 90:10 $n$-hexane/isopropyl alcohol, $1 \mathrm{~mL} / \mathrm{min}, 210$ $\mathrm{nm}): t_{\text {minor }}=16.4 \mathrm{~min}, t_{\text {major }}=20.0 \mathrm{~min}, 99 \%$ ee; $[\alpha]_{\mathrm{D}}^{25}=-16.24(c 0.5$, $\left.\mathrm{CHCl}_{3}\right)$

(S)-3-(2-Nitro-1-(thiophen-2-yl)ethyl)pentane-2,4-dione (12e). Yield $39 \mathrm{mg}, 76 \%$. Analytical data matched previously reported value. ${ }^{25 \mathrm{c}}$ HPLC (AD-H, 85:15 $n$-hexane/isopropyl alcohol, $1 \mathrm{~mL} / \mathrm{min}$, $210 \mathrm{~nm}): t_{\text {minor }}=12.0 \mathrm{~min}, t_{\text {major }}=15.9 \mathrm{~min}, 85 \%$ ee; $[\alpha]_{\mathrm{D}}^{25}=-87.62$ (c 1.0, $\left.\mathrm{CHCl}_{3}\right)$.

(S)-3-(1-(Furan-2-yl)-2-nitroethyl)pentane-2,4-dione (12f). Yield $44 \mathrm{mg}$, 91\%. Analytical data matched previously reported value. $^{25 a, c}$ HPLC (AD-H, 85:15 $n$-hexane/isopropyl alcohol, $1 \mathrm{~mL} /$ $\min , 210 \mathrm{~nm}): t_{\text {major }}=12.1 \mathrm{~min}, t_{\text {minor }}=16.1 \mathrm{~min}, 96 \%$ ee; $[\alpha]_{\mathrm{D}}^{25}=$ $-94.58^{\circ}\left(\right.$ c $\left.1.0, \mathrm{CHCl}_{3}\right)$.

(R)-3-(1-(4-(Benzyloxy)phenyl)-2-nitroethyl)pentane-2,4dione $(12 \mathrm{~g})$. Yield $65 \mathrm{mg}, 91 \%$. Analytical data matched previously reported value. ${ }^{25 \mathrm{e}}$ HPLC (AD-H, 70:30 $n$-hexane/isopropyl alcohol, 1 $\mathrm{mL} / \mathrm{min}, 210 \mathrm{~nm}): t_{\text {minor }}=11.1 \mathrm{~min}, t_{\text {major }}=14.7 \mathrm{~min}, 93 \%$ ee; $[\alpha]_{\mathrm{D}}^{25}=$ $-99.04\left(c\right.$ 0.25, $\left.\mathrm{CHCl}_{3}\right)$.

(R)-3-(1-(2-Methoxyphenyl)-2-nitroethyl)pentane-2,4-dione (12h). Yield $52 \mathrm{mg}, 90 \%$. Analytical data matched previously reported value. $^{25 \mathrm{c}}$ HPLC (IA, 98:2 $n$-hexane/isopropyl alcohol, $0.8 \mathrm{~mL} / \mathrm{min}$, $210 \mathrm{~nm}): t_{\text {minor }}=27.7 \mathrm{~min}, t_{\text {major }}=30.4 \mathrm{~min}, 90 \%$ ee; $[\alpha]_{\mathrm{D}}^{25}=-195.12$ (c $0.5, \mathrm{CHCl}_{3}$ ). 


\section{ASSOCIATED CONTENT}

\section{S Supporting Information}

Additional experimental details, copies of ${ }^{1} \mathrm{H}$ and ${ }^{13} \mathrm{C}$ NMR spectra for all new compounds, and HPLC chromatograms of Michael adducts. This material is available free of charge via the Internet at http://pubs.acs.org.

\section{AUTHOR INFORMATION}

\section{Corresponding Author}

*E-mail: tanyeli@metu.edu.tr.

\section{Present Address}

${ }^{\dagger}$ UNAM-Institute of Materials Science and Nanotechnology, Bilkent University, 06800, Ankara, Turkey.

Notes

The authors declare no competing financial interest.

\section{ACKNOWLEDGMENTS}

This work was supported by TÜBİTAK (110T870). M.I. thanks TÜBİTAK for a graduate scholarship. The authors thank İrem Bakırcı, Nurdan Sargın, and Merve Kapucu for HPLC measurements.

\section{REFERENCES}

(1) (a) Wurz, R. P. Chem. Rev. 2007, 107, 5570. (b) Spivey, A. C.; Arseniyadis, S. Top. Curr. Chem. 2010, 291, 233. (c) Müller, C. E.; Schreiner, P. R. Angew. Chem., Int. Ed. 2011, 50, 6012. (d) Spivey, A. C.; Arseniyadis, S. Angew. Chem., Int. Ed. 2004, 43, 5436.

(2) For some highly selective chiral DMAP analogues, see: (a) Vedejs, E.; Chen, X. J. Am. Chem. Soc. 1996, 118, 1809. (b) Ruble, J. C.; Fu, G. C. J. Am. Chem. Soc. 1997, 119, 1492. (c) Wurz, R. P.; Lee, E. C.; Ruble, J. C.; Fu, G. C. Adv. Synth. Catal. 2007, 349, 2345. (d) Spivey, A. C.; Fekner, T.; Spey, S. E.; Adams, H. J. Org. Chem. 1999, 64, 9430. (e) Kawabata, T.; Nagato, M.; Takasu, K.; Fuji, K. J. Am. Chem. Soc. 1997, 119, 3169. (f) Crittall, M. R.; Rzepa, H. S.; Carbery, D. R. Org. Lett. 2011, 13, 1250.

(3) Hodous, B. L.; Fu, G. C. J. Am. Chem. Soc. 2002, 124, 10006.

(4) Ishii, T.; Fujioka, S.; Sekiguchi, Y.; Kotsuki, H. J. Am. Chem. Soc. 2004, 126, 9558.

(5) Rabalakos, C.; Wulff, W. D. J. Am. Chem. Soc. 2008, 130, 13524.

(6) Wang, J.; Li, H.; Zu, L.; Jiang, W.; Wang, W. Adv. Synth. Catal. 2006, 348, 2047.

(7) Additionally, a molecular motor acting as a multifunctional chiral catalyst bearing 2-aminoDMAP and thiourea combination as the catalytic functioning entities has been reported very recently by Feringa. See: Wang, J.; Feringa, B. L. Science 2011, 331, 1429.

(8) (a) Singh, A.; Yoder, R. A; Shen, B.; Johnston, J. N. J. Am. Chem. Soc. 2007, 129, 3466. (b) Singh, A.; Johnston, J. N. J. Am. Chem. Soc. 2008, 130, 5866. (c) Nugent, B. M.; Yoder, R. A.; Johnston, J. N. J. Am. Chem. Soc. 2004, 126, 3418. (d) Dobish, M. C.; Johnston, J. N. Org. Lett. 2010, 12, 5744. (e) Davis, T. A.; Wilt, J. C.; Johnston, J. N. J. Am. Chem. Soc. 2010, 132, 2880. (f) Davis, T. A.; Johnston, J. N. Chem. Sci 2011, 2, 1076. (g) Dobish, M. C.; Johnston, J. N. J. Am. Chem. Soc. 2012, 134, 6068. (h) Davis, T. A.; Danneman, M. W.; Johnston, J. N. Chem. Commun. 2012, 48, 5578. (i) Davis, T. A.; Dobish, M. C.; Schwieter, K. E.; Chun, A. C.; Johnston, J. N. Org. Synth. 2012, 89, 380. (j) Shen, B.; Makley, D. M.; Johnston, J. N. Nature 2010, 465, 1027.

(9) For 2-aminopyridinium catalysts, see: (a) Takenaka, N.; Sarangthem, R. S.; Seerla, S. K. Org. Lett. 2007, 9, 2819. (b) Takenaka, N.; Chen, J.; Captain, B.; Sarangthem, R. S.; Chandrakumar, A. J. Am. Chem. Soc. 2010, 132, 4536. (c) Aguado, A.; Takenaka, N. Synlett 2011, 1259. Additionally, for the use of amidines as nucleophilic catalysts, see: (d) Birman, V. B.; Uffman, E. W.; Jiang, H.; Li, X.; Kilbane, C. J. J. Am. Chem. Soc. 2004, 126, 12226. (e) Birman, V. B.; Jiang, H. Org. Lett. 2005, 7, 3445. (f) Birman, V. B.; Li, X. Org. Lett. 2006, 8, 1351. (g) Birman, V. B.; Li, X. Org. Lett. 2008, 10, 1115. (h) Li, X.; Jiang, H.; Uffman, E. W.; Guo, L.; Zhang, Y.; Yang, X.; Birman, V. B. J. Org. Chem. 2012, 77, 1722. (i) Birman, V. B.; Jiang, H.; Li, X.; Guo, L.; Uffman, E. W. J. Am. Chem. Soc. 2006, 128, 6536. (j) Yang, X.; Bumbu, V. D.; Birman, V. B. Org. Lett. 2011, 13, 4755. (10) Jacobsen, E. N. Acc. Chem. Res. 2000, 33, 421.

(11) Miyabe, H.; Takemoto, Y. Bull. Chem. Soc. Jpn. 2008, 81, 785.

(12) Yoon, T. P.; Jacobsen, E. N. Science 2003, 299, 1691.

(13) (a) Wutts, P. G. M.; Greene, T. W. Greene's Protective Groups in Organic Synthesis, 4th ed.; John Wiley \& Sons Inc.: Hoboken, NJ, 2007. (b) Fuentes de Arriba, Á. L.; Seisdedos, D. G.; Simón, L.; Alcázar, V.; Raposo, C.; Morán, J. R. J. Org. Chem. 2010, 75, 8303. (c) Kim, Y. K.; Lee, S. J.; Ahn, K. H. J. Org. Chem. 2000, 65, 7807. (d) Mitchell, J. M.; Finney, N. S. Tetrahedron Lett. 2000, 41, 8431.

(14) Although Wulff (see ref 5) preferred the acronym "DMAP", here we find the word "2-aminoDMAP" more suitable since it is more informative on the mode of action of the catalaphore (implication of Brønsted basic nature due to its amidine structure; see also refs 8 and 9).

(15) (a) Guram, A. S.; Rennels, R. A.; Buchwald, S. L. Angew. Chem., Int. Ed. 1995, 34, 1348. (b) Louie, J.; Hartwig, J. F. Tetrahedron Lett. 1995, 36, 3609.

(16) 2-HaloDMAPs $2 \mathrm{a}-\mathbf{c}$ were prepared according to published procedure. See: Cuperly, D.; Gros, P.; Fort, Y. J. Org. Chem. 2002, 67, 238.

(17) See Supporting Information for a detailed discussion.

(18) Palladium-catalyzed selective mono- $N$-arylation of trans-cyclohexane-1,2-diamine was shown to proceed well for aryl halides as substrates. However, incompatability of 2-bromopyridine was reported. See: (a) Frost, C. G.; Mendonça, P. Tetrahedron: Asymmetry 1999, 10, 1831. See also: (b) Donati, D.; Ferrini, S.; Fusi, S.; Ponticelli, F. Synthesis 2003, 2518.

(19) Klapars, A.; Antilla, J. C.; Huang, X.; Buchwald, S. L. J. Am. Chem. Soc. 2001, 123, 7727.

(20) For a palladium-catalyzed efficient synthesis of $C_{2}$-symmetric bisDMAP 3, see: Yazıcıŏlu, E. Y.; Tanyeli, C. Tetrahedron: Asymmetry 2012, 23, 1694.

(21) Because of the high reactivity of $2 \mathrm{c}$, reactions were carried out at lower temperatures $\left(50^{\circ} \mathrm{C}\right.$ and room temperature) also, but the fate did not change; more or less the same selectivity was attained within $48 \mathrm{~h}$ of reaction time.

(22) Alakonda, L.; Periasamy, M. J. Organomet. Chem. 2009, 694, 3859.

(23) For a clear presentation of this highly emerging field, see: (a) Wang, Y.; Deng, L. In Catalytic Asymmetric Synthesis, 3rd ed.; Ojima, I., Ed.; Wiley VCH: New York, 2010; pp 59-94. For some seminal papers see: (b) Hiemstra, H.; Wynberg, H. J. Am. Chem. Soc. 1981, 103, 417. (c) Sigman, M. S.; Jacobsen, E. N. J. Am. Chem. Soc. 1998, 120, 4901. (d) Corey, E. J.; Grogan, M. J. Org. Lett. 1999, 1, 157. (e) Okino, T.; Hoashi, Y.; Takemoto, Y. J. Am. Chem. Soc. 2003, 125, 12672.

(24) (a) Oh, S. H.; Rho, H. S.; Lee, J. W.; Lee, J. E.; Youk, S. H.; Chin, J.; Song, C. E. Angew. Chem., Int. Ed. 2008, 47, 7872. (b) Luo, J.; Xu, L.-W.; Hay, R. A. S.; Lu, Y. Org. Lett. 2009, 11, 437. (c) Rasappan, R.; Reiser, O. Eur. J. Org. Chem. 2009, 1305. (d) Kimmel, K. L.; Robak, M. T.; Ellman, J. A. J. Am. Chem. Soc. 2009, 131, 8754. (e) Kimmel, K. L.; Robak, M. T.; Thomas, S.; Lee, M.; Ellman, J. A. Tetrahedron 2012, 68, 2704.

(25) For some recent examples of acetylacetone addition to nitroolefins, see: (a) Malerich, J. P.; Hagihara, K.; Rawal, V. H. J. Am. Chem. Soc. 2008, 130, 14416. (b) Bassas, O.; Huuskonen, J.; Rissanen, K.; Koskinen, A. M. P. Eur. J. Org. Chem. 2009, 1340. (c) Jiang, X.; Zhang, Y.; Liu, X.; Zhang, G.; Lai, L.; Wu, L.; Zhang, J.; Wang, R. J. Org. Chem. 2009, 74, 5562. (d) Peng, F.-Z; Shao, Z.-H; Fan, B.-M; Song, H.; Li, G.-P; Zhang, H.-B J. Org. Chem. 2008, 5202. (e) Wang, J.; Li, H.; Duan, W.; Zu, L.; Wang, W. Org. Lett. 2005, 7, 4713. (f) Wang, C.-J.; Zhang, Z.-H.; Dong, X.-Q.; Wu, X.-J. Chem. Commun. 2008, 1431. (g) Almasi, D.; Alonso, D. A.; Gómez-Bengoa, E.; Nájera, C. J. Org. Chem. 2009, 74, 6163. (h) Nemoto, T.; Obuchi, 
K.; Tamura, S.; Fukuyama, T.; Hamada, Y. Tetrahedron Lett. 2011, 52,

987.

(26) Kaik, M.; Gavroński, J. Tetrahedron: Asymmetry 2003, 14, 1559. 